\title{
Reconfiguration of Women's Environmental Lover (Configuration of Environmentalist Women)
}

\author{
Elly Prihasti ${ }^{1}$, Wuriyani ${ }^{2}$ \\ ${ }^{1,2}$ University of Medan (UNIMED), Medan, Indonesia \\ 1ellyprihasti@unimed.ac.id, ${ }^{2}$ Wuriyani.elly@gmail.com
}

\begin{abstract}
The women's movement continues to grow but their struggles continuesly struggle in Domestic challenge, power and economy. They are considered unfit. Power also threatens in voicing the protection of the natural environment. The description of women's struggle is contained in the text of the Women's Batak Opera on the edge of the Lake by Lena Simanjuntak. This opera text restores the identity of women who are closer and care about the environment that is starting to break down, also to values that are starting to disappear. Inductive methods used range from general to general or general problems. The problem analysis starts from the presentation of evidence in the text which is then dialogue with the concept of ecofeminism. The results show that it is not easy for women to express a voice of concern for nature, even though it has been discourse in the context of their cultural history. Furthermore, due to cultural changes that prioritize the interests of individuals and humans from ecology. This is a strong reason for some women to resist changes in voicing and releasing the natural damage caused by human activities.
\end{abstract}

Keywords: identity; women; environmentalists

\section{Introduction}

Literary works in the midst of political polemic and technological prestige continue to be excluded by film and online media, still have their own way of life in discussing the phenomenon of society. The development of literature continues to develop through its themes, for example women's issues and the diversity of their studies. The birth of Feminism movement also influenced the trend of content and literary studies. Literary studies has been talking about the marginalization of women writers by writers majority of men, gender equality, women's representation in literature either write an male or female, regard the destruction of nature by gender, parenting, and others.

Problems are faced by women in literature although it has been heavily linked the varieties aspects of life, remains a theme that continues to warm discussed. The theme of women in literary works can be studied in various ways and perspectives. Literary works can also be used as a proof of how woman is used by the author. Women in Indonesian literature both old and new that is identical to weak, soft, submissive and carrying are as the characters' women. If there are women who are firm and brave to fight, then it is considered improper by the environment and even other women. This is also the case with $O B$ $P d P D$ text, which inspires women to keep close and care for nature, even though they are insulted and challenged.

Lena sharpens the illustration of female characters by raising the legend of Lake Toba to women today. Appointment legend, the authors interpret, as a way is to show the alteration of one's identity. Opera Batak text is written on 24 pages left the issue of women's identity in related to nature. The Change of identity in different times is to be reasonable because there is the social, economic and cultural rights are also different. The identity of women who have caring, disliking a damage, and women who are affected by the damage so they must care about their environment. These three identity categories are formed because there are different interests, social classes, and economics. But it's to be interesting when that identity is 
made connecting with natural issue. Therefore, changes in female identity in the text of this OBPdPD is be interesting to study, namely "Why does nature disaster on OBPdPD text establish the identity of women into mutual contradiction?"

\section{Method}

The focus of this paper's discussion is the identity of the women's bag in the text "Opera Batak Women on the Edge of the Lake" by Lena Simanjuntak (Simanjuntak, 2013). The method used to collect and analyze the variables of this study is the inductive method. The inductive method was chosen as the knife of analysis because it is in accordance with the contents of literary works that present events after events which then form a more complete theme. Issues which are dismissed from specific matters then to the general public will deepen these findings.

Primary Data this paper is sentence, theme, and a series of events involving figures of women in text Opera ${ }^{1}$. The data was obtained by the technique's listening. The listening technique is used to obtain data units of information (diction and sentence) and themes, which are then analyzed in contradictory dialogues. This analysis technique begins by contrasting all the facts found in the corpus of research as a source of primary data. Data in the form of themes are then dialogued with sources that have been collected so that answers to the problems discussed are found, namely the identification of women with nature in the OBPdPD text.

\section{Discussion}

The basis of this theory tries to refer to some experts' opinions regarding women's identity and Vandana Shiva's eco-feminism and especially the reductionism of women's knowledges. Germaine Greer states that identity is influenced by our relationships with others, with the world we live in, can be recognized and measured. Identity according to Jenkins (2008, page. 2-5) is the human capacity regarding 'who' and 'what' is inherent in every action carried out by an individual who can show himself and certain members of society. Barker (2008: 174-175) explains that identity is both personal and social and marks someone as equal or different from others. Identity is cultural in 'all its aspects', it is specific according to a certain space and time. This means that forms of identity can change and are related to various social and cultural contexts. Vignoles (2011: 3) reveals that identity can be defined through three different levels: individual, relationship and collective. The difference between the three can be understood as the difference between the forms of identity content and can be understood by referring to the processes and stages experienced when identity is formed, maintained or actually changes. According to Faruk (2007, p. 6), this individuals meeting with this social identities can then lead to conflicts or cultural conflicts because of incompatibility or differences in norms in the society encountered. So, identity is something

\footnotetext{
${ }^{1}$ This dissertation material object data has been reviewed in part on a dissertation grant funded by the Ministry of Research and Technology with the Letter of Agreement for the Implementation of Research Grant No: 045A/UN33.8/LL/2017, and researchers have published at: 1) Lingua Journal Vol 13, No 2 (2017): July 2017 page. 151-165 entitle "Negosiasi Mitos Hubungan Perempuan dengan Alam dalam Teks Opera Batak Perempuan di Pinggir Danau Karya Lena Simanjuntak (Tinjauan Eko feminisme)". https://journal.unnes.ac.id/nju/index.php/lingua; 2) Proseding 1st Inteernational Conference on Education, Literture, and Arts (Icela) Mey 17-18, 2017 bay Faculty of Languages and Arts Universitas Negeri Jakarta, ISSN 2579-8847 dan The 2nd UGM International Conference on Southeast Asia Studies (ICSEAS 2017) 27-28 September 2017.
} 
that is inherent in the individual 'who' and 'what' that can make the same at the same time different in the scope of culture and can cause mismatches between them.

Shiva (Shiva, 1997, pp. 7-12) sees a disturbance in the relationship between women and nature because of the view of reductionism of life knowledge that uses western standards. The view of reductionism has shifted and changed the natural life knowledge to the results of the thinking of experts seen through development. The concept of a life which is oriented towards men and brings benefits results in nature and women being seen as 'other', passive, which are used and oppressed to fulfill the passions that are not controlled by men and capitalists.

According to Shiva and Mies (Shiva \& Mies, 2005, p. 14) eco-feminism does not look at human needs based on primary and tertiary needs (regardless of cultural background, ideology, race, politics, economic system, and class differences), culture is part of the stretch to survive. The freedom is to love each other and do something productive in accordance with the will of nature; knowledge is a basic need for survival.

\subsection{Women's Identity in Relation to Nature}

Identity refers to 'who' and 'what' (Jenkins, 2008, pp. 2-5). Based on OBPdPD text there are three women who have different attitudes, behaviors, and languages, especially in dealing with nature. The identity of three women in relation to nature is empathy, sympathy, and apathy. When the researchers returned to the definitions Barker (2008: 174-175) the identity of the person can be a 1 and so pesky that can be different and the same. The differences of identities of the three women naturally happened. However, this is different when striking differences occur in the same gender, region, and culture. As explained by Faruk (2007, p. 6) is the meeting of individual and social identities will lead to conflict.

Identity conflict among three women was obtained from three dominant voices representing their views on nature. Based on the classification, in the OBPdPD text, three female identities were found. First, Ematis women are their appearance of his at the beginning of the story until the end of the story is represented as the most dominant. They struggles their relationship with nature, care about the destruction of nature, and care to the burden of other women because of natural changes. Second, women only pretend to care and tend to be unstable in understanding the relationship with nature. Third, the apathetic women who is drawn as the woman who started the indifferent nature and tend to be arrogant, even leaning against another woman who has aggressiveness or empathy restricted in nature.

The voices of Women have an example could be seen in the short dialogue mother figure "Ibu Ikan: .... Hapus air matamu, ikat rambutmu, tegakkan kepalamu. Pukul genderang, tebarkan senyummu dan nyanyikan dengan nyaring lagu peringatan, .... Katakan pada setiap orang yang kau temui, kita masih bisa merubah keadaan" (Mother Fish: ... Wipe your tears, tie your hair, raise your head up. Beat the drum, spread your smile and sing loudly the warning song. Tell everyone you meet, we can still change the situation). Mother's character said that the women who are moaning and crying to get up. Mother also assured that they could still change the situation around him. The word "wipe your tears, tie your hair, raise your head" shows that something is built to replace the assumption that has been dominant and taught. The call to be something contradictory, is not a natural thing, and not uncommon in women at lake edge.

These words can be interpreted as information, that there are new views that try to unpack existing ones. The woman was previously described as a human who cries, breaks down hair, and bows her head or is weak. This description of the natural woman for example in the 
fragment of the Women's Voice dialogue: "... You tell the women to go out and scream in the street. Isn't that violating his nature as a gentle human? Wouldn't it be better for him at home to educate his children or take care of his family ... "This piece of dialogue was spoken by female leaders who were apathetic about the environment and the lives of other human beings.

The term empathy, sympathy, and apathy is referring to Big Indonesian Dictionary (KBBI, 2008, p. 20,83,91,1352) below:

Apatis $a$ (apathetic) acuh tak acuh; tidak peduli; masa bodoh. Arogan $n$ (arrogant) perasaan hati yang menganggap diri lebih hebat; lebih baik dan sebagainya dari pada orang lain,yang terekspresi melalui sikap yang suka memaksakan kemauan sendiri; congkak. 388 empati lémpati/ n kemampuan menghadapi perasaan dan pikiran orang lain Simpati (sympathy) rasa kasih; rasa setuju (kpd); rasa suka; 2 keikutsertaan merasakan perasaan (senang, susah, dan sebagainya) orang lain; bersimpativ1 menaruh kasih (kepada);suka (akan): banyak rakyat yg kpd pemimpinnya; 2 ikut serta merasakan perasaan orang lain: banyak orang yg atas kemenangan tim itua bersifat membangkitkan rasa. Empati lémpati/ n kemampuan menghadapiperasaan dan pikiran orang lain.

The contradiction in identifying new women and the dominant ones continues to unravel through language that forms a series of stories that shape the scenes, conflicts, and ideas of the characters. The two dialogues above show that the figures dialogue with one another about their ideology. According to Althusser (2008, pp. 34-63) ideology has several forms. First, ideology has no historical aspects. Ideology is throughout history so it is constantly there and is no longer historical. Second, ideology is a 'representation' of the relations of imaginary individuals in their real conditions and existence. Idelogy operates on an individual level so that it is a hegemony control that exists in each individual. Third, ideology interprets individuals as subjects. Ideology exists through the subject and for the subject so the object will be explained by the subject subjectivity.

This ideology becomes something that can't be separated from everyday life and causes someone to act as he wants. The subjects are trying to maintain their subjectivity, even thought within themselves are also happened a process dialogues about their ideology. This is what is seen in female leaders, each of whom has different interests and thoughts. However, they are not aware of these differences so they try to hegemony other women.

The ideology that is maintained by each subject in order to unpack and some who want to continue to legalize. Ideology that is built on one side forms a series of stories that imply a view that preserving or preserving nature is not a woman's business and also not a man's business. The author is as a subject who processes the object to form a new ideology to be conveyed to the reader. According to (Althusser, 2008) the author has Soft ideology in his writing which is conveyed through language which is then transmitted to his readers. The author's messages have ideological values. Althusser explained further, the author as a subject had carried out the interpellation process .

New identities created through speech and messages give rise to contradictory views on life between humans, both women and men. This view of contradiction occurs because of differences in seeing the relationship and responsibility of humans with the natural environment . 


\subsection{Privatization of Freedom of Stay in the Family}

Perempuan/ibu: "Kau ciptakan aku sebagai simbol kesuburan. Kau basuh aku dengan kelembutan curahan air dari langit yang singgah di atas daun menjadi embun pada pagi hari dan mengalir di selah-selah tanah menuju liukan sungai, berhenti sejenak menyapa danau melangkah ke lautan lepas. Kau letakkan nyanyian mantra di lidahku untuk memelihara bumi. Tetapi kenapa kau biarkan keindahan ciptaan-Mu dirusak dan dinodai, oleh kerakusan dan nafsu untuk merusak kebersamaan. Bumi ini semakin panas karena ulah manusia. Lihat perempuanperempuan di pinggir danau merintih melihat anak-anaknya terseot-seot mencari air bersih. Sementara banyak bapak menghirup cairan alkohol. Sampai mereka mabuk melarikan diri dari masalah sampai akhirnya melakukan kekerasan".

Andungan represents the existence of dialogue in the subject / woman is about symbol that is given by Creator or God. Mother's character on one side became a symbolic and dimensioned subject. The sentences are as "Kau ciptakan aku sebagai simbol kesuburan.... Kau letakkan nyanyian mantra di lidahku untuk memelihara bumi" show as regisnation is as subject that keeps Earth. In addition, it can also be interpreted as a protest because the symbol of fertility and spells that have been placed as caregivers are damaged by greed and human lust.

The new identity of women as guardians of the earth is told backwards by the author, which starts from why the mother figure is a symbol of fertility. The mother figure in the OBPdPD text is a goddess from heaven because of the consequence of finally living in Bumli. This view of the mother's character is parallel with Thuner Concept. Thuner (1994, page. 14-15) explains that the figure of a good and ideal mother is created many times and is often associated with women who have given birth to a child. Along with the development of human civilization, the ideal mother figure begins with the worship of the goddess. Even though the goddess is worshiped, they are paradoxical. On the one hand they are believed to have cared for and looked after the universe and humans. On the other hand, they are believed to damage and destroy. Women, especially mothers are considered to have the ability to create life from their bodies, but they are also considered to have the ability to destroy. In the OPBPdPD text the mother is depicted as an honorable woman because she is a goddess and who gives birth, but in later developments it is seen as a barrier to the development of the times.

The job desk makes some places for women as caregivers and cares in the domestic realm is the cause of the limited interaction between women and nature. Women in the period before Lake Toba occurred in $O B P d P D$ text is identified as a beautiful, gentle and firm housewife. The ideal woman is in the domestic sphere. This change in the concept of an ideal woman shows that women become objects that will always change depending on the subjectivity of the named subject. The identity of women during the transition period did not change significantly in the period before the occurrence of Lake Toba. Women who have been identified as guardians of nature through mother's care shift to the domestic realm, relations with nature are limited to those that occur at home. This shift can be seen in the expertise in weaving mats, choosing rice for seeds, and gathering spices, which can be done at home. This woman's figure is emphasized in her feminine nature. Simone de Beauvoir (Beauvoir, 2003, p) in his book The Second Sex states that "a person is born as a woman; but to be female ". The point of his view is that "woman" is a concept that exists only in relation to men, not innate. 
This identity change occurs after women enter patriarchal power or in a system created for the benefit of men in the domestic sphere. Woloch (1984, pp. 495-496) explained that the domestic ideology portrayed women as housekeepers, caretakers of children. This domestic role seems to be more passive and uncompetitive and less prominent than men engaged in the public sphere. It make a new perception that women are beautiful, healthy, educated and focused on her husband, children and household is a description of the ideal woman. Thus, women who are active in environmental voices or who are still in contact with nature are not classified as ideal, even though they aim to meet their household needs.

\section{Women Womeni L upus}

Suara Penentang: Hai perempuan berhentilah mengoceh! Tak kau lihat kesetiaan Samosir menanti bayangan istrinya? Dan kau perempuan tau apa.... dengan seluruh pengolahan alam. Kami berusaha, bekerja keras untuk memikirkan bagaimana agar kelaparan dan kemiskinan dapat di atasi. Bagaimana masyarakat hidup sehat dan berpendidikan. Hidup damai dan sejahtera. Pergilah kau masuk dalam dunia primitifmu yang selalu melihat sesuatu dengan sakral sementara orang lapar.

This above dialog shows the fight between women with women, Faruk mentions the practice of women womeni lupus. Faruk (2000, p. 93-96) explained that this battle was generally a battle for attention. Their activity is not an activity that becomes a relation of the subject's function, but an objectivity relationship. The attention that is drawn to the $O B P d P D$ text here, is not directly directed at the husband, even though it is actually 'yes'. The attitudes and views of these upper class women are actually carried out to support the status of themselves and their families. They save themselves as people who feel better know about the problems that are happening. They do not realize that they have humbled other women to mempertah a were playing status has made objects.

The female characters that are raised are; Women's Voice, Opposing Voice, and Mother. The dialogue is happened in mother and female characters bring a identity war between of the old with the identity of the new. The old identity is an established order in the community where this literature was made. A new identity is an identity that is built by such authors. The ideology was built by the authors through the battle of the characters, both regarding their own identities or others . Different perceptions are raised by asking again the natural role and the role that is intentionally attached to them, for example in the following dialogue excerpt.

Suara-Suara Yang Menentang: Tutup mulutmu perempuan. Lebih baik kau pulang mengurus rumah tanggamu daripada omong kosong. Jangan kau hanya mengeluh. Penduduk dunia semakin meningkat, apa jalan keluarmu untuk mengatasi kebutuhan manusia? Apakah kau sampai hati melihat petani yang bekerja membanting tenaga tetapi hanya menuai sekedar untuk cukup makan. Bagaimana masa depan anak-anaknya?

Suara Perempuan: Bukankah itu pekerjaan yang sia-sia. Kau suruh para perempuan keluar rumah dan berteriak-teriak di jalan. Bukahkan itu melanggar kodratnya sebagai manusia yang lembut? Bukankan lebih baik ia di rumah mendidik anakanaknya atau menjaga keluarganya agar hidup dengan harmoni? 
The Sentence is "Tutup mulutmu perempuan. Lebih baik kau pulang mengurus rumah tanggamu dari pada omong kosong. Jangan kau hanya mengeluh" shows their emphasis confirmation once the identity of the ideal woman, the housewife passive. The sentence also shows that there are efforts to establish become women, women who obey, not much to say, and keep the house. The dialogue can be represented that what constitutes 'being a woman' is not only men/ patriarchy but by women. stating that women are also parties who have strengthened patriarchal power. It looks at how women represent other women, who are considered to be below or economically have been marginalized.

Ibu Ikan: Kodrat katamu? Harmoni? Puiiih..... Perempuan melahirkan itu memang kodrat. Tetapi perempuan harus lembut dan menutup mulut, itu bukan kodrat itu adalah pemasungan! Apa maksudmu dengan harmoni? Harmoni itu hanya mitos yang disebarkan untuk menutup mulut dan menutup mata orang-orang demi kepentingan kekuasaan. Bukan kata-kata hampa harmoni yang kita butuhkan. Kita butuh saling menghormati.

Lebel is as the creator of harmony in the household is in line with Wolch's opinion (Woloch, 1984, pp. 495-496), namely the task of cleaning the house to reverse women in their traditional role in the domestic sphere and reinforcing the domestic ideology. The harmony in the dialogue section above is an unconscious act of the women themselves that they have confirmed their domestic ideology.

Women subordinate other women who get better facilities and livelihoods. The passivity and tenderness of women are reaffirmed by emphasizing the creation of family harmony. A woman in a certain class distorts herself / a woman as the creator of harmony, for example in a fragment of dialogue ... "Bukahkan itu melanggar kodratnya sebagai manusia yang lembut? Bukankan lebih baik ia di rumah mendidik anak-anaknya atau menjaga keluarganya agar hidup dengan harmoni?"

Meaning of the code of honor between the voices of women and mothers occurred. The nature of a woman's voice, representatives of the era of development are passive housewives who do not complain much and stay at home in other words accept what they are. However, according to Mother the nature of women who actually are pregnant, giving birth, and breastfeeding.

\subsection{Between Conscience and Interest}

Women's identity has subsequently undergone a drastic change, which is to surrender nature to those who are considered to know better or rule. The view that considers work in vain when women get closer to nature and get to the streets. During this period implicitly there was an affirmation of the passive identity of women at home and when active in the public, working for capitalist interests. However, this inauguration is not an easy thing because the author presents female characters who contradict each other. The contestation is took place between women and women themselves.

The domestic ideology that is endorsed by women whose lives are more sophisticated is actually a form of their inability to deal with conditions caused by a tighter division of labor from marginalized women. So that when the marginalized woman is motivated to rise up to voice the environmental changes around her, it is seen as a fruitless work and violates the nature of women. According to Engels' theory which is supported (by the results of Burkett's research) 
explains the fact that the division of labor is sexually harder carried out in the middle class and up, but not in the lower classes. Many people in the lower classes, especially women, work outside the household and are therefore in a stronger economic position. Lower class women are more independent than men (Budiman, 1982, p. 28).

Suara Perempuan: Bukankah itu pekerjaan yang sia-sia. Kau suruh para perempuan keluar rumah dan berteriak-teriak di jalan. Bukahkan itu melanggar kodratnya sebagai manusia yang lembut? Bukankan lebih baik ia di rumah mendidik anakanaknya atau menjaga keluarganya agar hidup dengan harmoni?

This exploitation of nature causes differences in the lives of people, especially those living near lakes. Some women consider that it is natural for nature to be utilized in various ways to meet the increasing human needs. $M$ hey these are not directly described as women who live all-sufficient and enjoy the fruits of the exploitation of nature. Women still consider the different roles between men and women. The battle that is seen from the activities of women in the dialogue above and 163 below, also illustrates that there are two functions of relations that are built up.

Ibu Ikan: Hai para perempuan berhentilah merintih dan menangis. Hapus air matamu, ikat rambutmu, tegakkan kepalamu. Pukul genderang, tebarkan senyummu dan nyanyikan dengan nyaring lagu peringatan sambil, menyusuri jalan-jalan, lorong dan setiap sudut bumi. Katakan pada setiap orang yang kau temui, kita masih bisa merubah keadaan.

Motivating activities carried out by the mother figure to women in power, showing they are as subject who tried to beseech women who whimper as attention givers, and have the ability to change circumstances so that nature is maintained. The mother's dialogue is actually a contradiction, one side being the 'subject' who wants to make the subject on the other. On the other hand, when the process of making the subject takes place it has already become an object of women. Objectifying is done by Opposition Voice. The opposition Voice pretends to seem as subject, who unwittingly has confirmed that he is the object of the male, patriarchal and capitalist.

These differences of opinion occur because of differences in economic and social classes. Women who also enjoy changing times and in established economies and societies tend to think that nature should be exploited. The woman represented by the Opposing Voice also believes that women do not need to demonstrate until they go down the road just to voice the destruction of nature, but women should properly carry out their nature and stay at home. These marginal women or those in the lower class have to look for water outside the home for their household needs. These water-seeking habits have trained to position them in a stronger economy, compared to middle-class women who are accustomed to being provided for in their homes or around the house. They are looking for clean water for household needs, the distance is further away.

This class difference is the cause of identity views about women's closeness to nature. Women in the upper classes are women who have no more contact or direct contact with nature in order to meet their household needs. Meanwhile, women in the lower classes still show closeness to nature because there is no direct contact with nature in order to find and take good clean water. Sihva (Shiva \& Meis, 2005) emphasizes the closeness of women to 
nature seen in their routine in the forest. Forest is as a place to find fuel to meet the needs of the household. In OBPdPD text, the closeness of women to nature occurs due to the routines of lower class women in rivers and lakes in the context of finding clean water for their household needs.

\section{Conclusion}

The differences of identities among some women have caused conflict between them that are culturally and where living together is on the edge of the lake. Women who feel have the opportunity and comfort better in economic and social fields become less concerned with individuals from other classes. Ultimately the attitude removes the identity of togetherness, sympathy, and empathy in human beings. The female identity is able to conclude less concerned with the nature because the ability to make money that I owned and considers the way of life they are most ideal.

Human or female identity that is still oriented to needs, social class, and economy can be a barrier to the success of expressing concern for nature. The obligation to protect the environment is not only for poor women who still interact directly with nature. Environmental damage can be slowed only if all the women and men involved in the mission.

\section{Acknowledgments}

Thank you to the Directorate of Research and Technology and Community Service of the Ministry of Research and Technology, Technology and Higher Education for funding this doctoral dissertation grant. Dr. Wening Udasmoro, DEA as Promoter and Dr. Lono Lastoro Simatupang, M. Hum. as a copromotor. Gadjah Mada University is as an institution that publishes Dissertation and Medan State University which has allowed researchers to undertake doctoral education at UGM.

\section{References}

Althusser, L. 2008. Tentang Ideologi: Marxisme Strukturalis, Psikoanalisis, Cultural Studies. (O. V. Arnof, Trans.) Yogyakarta: Jalasutra.

Faruk. 2007. Belenggu Pasca-Kolonial, Hegemoni \& Resistensi dalam Sastra Indonesia. Yogyakarta: Pustaka Pelajar.

Jenkins, R. 2008. Social Identity, Third Edition. London and New York: Routledge.

KBBI. 2008. Kamus Besar Bahasa Indonesia. Jakarta: Pusat Bahasa Departemen Pendidikan Nasional.

Shiva, V. 1997. Bebas dari Pembangunan: Perempuan, Ekologi, dan Perjuangan Hidup di India. Jakarta: Obor Indonesia.

Shiva, V., \& Mies, M. 2005. Ecofeminisme Perspektif Gerakan Perempuan dan Lingkungan.

(K. Ismunanto, \& Lilik, Trans.) Yogyakarta: IRE Perss.

Simanjuntak , L. 2013. Opera Batak Perempuan di Pinggir Danau. Yogyakarta: Kata Kita.

Thurer, S. L. 1994. The Mythe of Motherhood: How Culture Reinvents Good Mother. Amerika Serikat: Penguin Group.

Vignoles, V. L., Seth , J. S., \& Koen Luycky. 2011. Handbook of Identity Theory and Research. New York: Springer.

Woodward, K. 1997. Identity and Difference. London: Sage Publications Ltd. 